\title{
DISEASES AND INJURIES OF HIMALAYAN PINE SEED FROM CULTURE GROWN ON DEPOSOL
}

\author{
Vesna GOLUBOVIĆ ĆURGUZ1, Katarina MLADENOVIĆ ${ }^{2}$, \\ Biljana NIKOLIĆ ${ }^{2}$, Snežana RAJKOVIĆ ${ }^{2}$
}

\begin{abstract}
Approximately 100 semi-ripe cones were harvested from a young forest culture of Pinus wallichiana grown on loamy deposol. Opening of cone scales and dropping of seed grains were induced under laboratory conditions. The number of damaged seeds and the type of damage, as well as the total and average number of seeds per cone, were determined on the population and individual levels. The intensity of damage was expressed in percentages. The analyses for determination of the present fungi and the intensity of their attack were conducted by placing the seeds onto a nutritious MEA bed and moist filter paper in Petri dishes. In order to establish the presence of insects, cones with visible damage were collected in the field. These cones were then examined in the laboratory and placed into photoeclectore for further growing.
\end{abstract} abietella

Key words: Pinus excelsa, Himalayan pine, Penicillium, Alternaria, Dioryctria

\footnotetext{
${ }^{1}$ Vesna Golubović Ćurguz Phd, Assistant Research Professor, the University of Belgrade, Faculty of Forestry

${ }^{2}$ Katarina Mladenović, Graduate Engineer, Research Assistant, Institute of Forestry, Belgrade

${ }^{2}$ Biljana Nikolić Phd, Research Associate, Institute of Forestry, Belgrade

${ }^{2}$ Snežana Rajković Phd, Principal Research Fellow, Institute of Forestry, Belgrade
}

Acknowledgement: This paper was financed under the framework of the project of the Ministry of Science and Technological Development of the Republic of Serbia TR 31070 


\section{BOLESTI I OŠTEĆENJA SEMENA U KULTURI HIMALAJSKOG BORA GAJENOG NA DEPOSOLU}

Izvod: Iz mlade šumske kulture Pinus wallichiana osnovane na ilovastom deposolu, sakupljeno je oko 100 poluzrelih šišarica. U laboratorijskim uslovima indukovano je otvaranje njihovih plodnih ljuspi i ispadanje semena. Broj oštećenih semenki $i$ vrsta oštećenja kao $i$ ukupan i prosečan broj semenki po šišarici utvrđeni su na populacionom $i$ individualnom nivou. Intenzitet oštećenja iskazan je $u \%$. Analize za determinaciju prisutnih gljiva kao i intenziteta njihovog napada uradjene su postavljanjem semena na hranljivu MEA podlogu i vlažan filter papir u petri posudama. Radi utvrđivanja prisustva insekata sakupljane su šišarice, sa vidljivim oštećenjima, na terenu. Šišarice su zatim pregledane u laboratoriji i stavljane u fotoeklektori radi daljeg gajenja. abietella

Ključne reči: Pinus excelsa, Himalayan pine, Penicillium, Alternaria, Dioryctria

\section{INTRODUCTION}

Himalayan pine (Pinus wallichiana A. B. Jacks.) is a conifer whose areal spreads over southern and western Himalayas, eastern Afghanistan, north-east Belugistan, northern Burma and Yunnan province in China. In the Himalayas it appears in pure and mixed stands, on the elevation between 2,000 and 2,000 meters. It is the second most important tree species in the Himalayas, following the Himalayan cedar. It has wide ecological amplitude, with the elevation border of $1,800-3,500$ meters above the sea level. The Himalayan pine grows up to $50 \mathrm{~m}$ in height. The bark on the trunk of fully grown trees has scale-like cracks while the crown is in the shape of a pyramid, in particular in solitary trees, whose branches drop to the ground. The needles and cones of this five-needle pine are exceptionally long (Vidakovic 1982), which further contributes to its decorative value, and it is therefore frequently encountered in parks in this region.

Himalayan pine is characterized by fast growth, early flowering and seed production, high resistance to frost in urban conditions (Bunusevac 1959) and high resistance to fungal disease Cronartium ribicola and entomological damage from Pissodes strobi, both far more frequent causes of disease of its North American kin, Eastern white pine, Pinus strobus L. (Vidakovic1982 and the quoted references).

In Serbia, the Himalayan pine may be encountered in parks in major cities or around homes as solitary trees or in smaller groups. Although it grows best on deep, fresh soils, the stands of this species also grow well and have a solid increment on more barren soils, damaged by exploitation of coal (Drazic, 1997). Several authors have already studied the group and individual variability of this species in park plantations in our conditions, related to speed of growth and increment, flowering, seed production and adaptability (Milojevic-Nikolic 1991, 1992; Milojevic 1989; Nikolic 1996, 1997), as well as on the success of establishing and developing artificial cultures on deposits of strip mines (Nikolic et al, 1998, 2004). Moreover, there are preliminary results regarding individual 
resistance of grown trees of Himalayan pine to some phytopathological diseases of seeds and sprouts (Golubovic - Curguz and Nikolic, 1999). In order to undertake appropriate measures, knowledge on pest bionomics is vital because of trophic links of certain species of insects, cultures and pine stands. Economically significant types of moths are lately appearing in masses, which may lead to total destruction of seed harvest and consequently make it impossible for forests to regenerate naturally.

\section{MATERIAL AND METHODS}

In a 25-year-old forest culture of Himalayan pine, spreading over an area on 0.9 ha and grown on loamy deposol, deposit of lignite strip mine in Kolubara Mining Basin, Barosevac locality, in the second half of September approximately 10 semi-ripe cones were collected from 10 trees each. Under laboratory conditions (in a dry chamber at $35^{\circ} \mathrm{C}$ ), opening of cone scales and dropping of seed grains were induced over the following month. In this process, substantial damages from insects and fungi were found on cones and seeds. The number of damaged seeds and the types of damage, as well as the total number of seeds per cone, were tested on the individual level (for each tree separately) and population level (the average of all trees). The intensity of damage was expressed in percentages (the number of damaged cones versus the total number of cones). Seed production was expressed in the number of seeds per cone.

Laboratory analyses of the health condition of seeds brought from the field were conducted in the Institute of Forestry. The seeds were first sterilized in $\mathrm{Na}$ hypochlorite with $1.5 \%$ content of active chlorine, and then rinsed out three times in sterile water and placed in Petri dishes. The bottom of the Petri dishes was lined with double layers of filter paper soaked in $20 \mathrm{ml}$ of sterile water. The second portion of the seeds was placed into Petri dishes with nutritious MEA bed, five seeds per dish. All Petri dishes with seeds were placed in the thermostat at the temperature of $22 \pm 1^{0} \mathrm{C}$. After that the control of present microflora was conducted, where their morphological appearance was determined along with the ability for seed production on artificial beds and the size of seed-bearing bodies and reproductive organs.

The keys used for determination of fungi keys were by B.C. Sutton (The Coleomycetes, 1980), J.V. Carmichael et al (Genera of Hyphomycetes, 1980) and R.W.G. Dennis (British Ascomycetes, 1978).

The collected cone samples were examined in the laboratory of the Division for Plant Protection of the Institute of Forestry. The samples containing moth caterpillars were cultivated for imagos. Upon eclosion the imagos were destroyed, preserved and identified. The preserved units and photographic documentation is kept in the archive of the Institute of Forestry in Belgrade. 


\section{RESULTS}

\subsection{Seed damages caused by the presence of fungi}

Seed damages caused by the presence of fungal organisms were recorded in $18.28 \%$ of cones (on the average) with very high individual variability (in $0-50 \%$ of cones per tree) (Graph 1). Even though the microscopic examination revealed no symptoms of disease in seeds of trees number 1, 3, 4 and 5, samples from all trees were placed onto nutritious beds. Laboratory analysis confirmed that only the seed from tree no. 1 is free from the presence of fungi. Seeds from other analyzed trees showed presence of fungi from genera Alternaria, Fusarium, Penicillium, Trichothecium (tab. 1). The most frequently found were fungi from the genus Penicillium (in $50.4 \%$ of the analyzed seeds), while the least frequent were fungi from the genus Fusarium (3.5\% of the analyzed seeds).

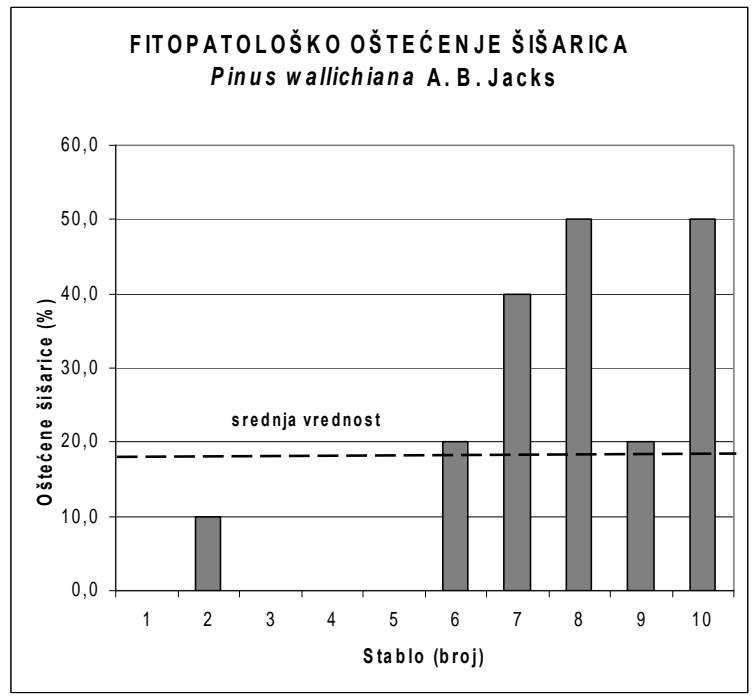

Graph. 1. Individual and average damages of cones by fungi

Table 1. The intensity of the presence of fungi on seeds of the analyzed trees

\begin{tabular}{|c|c|c|c|c|}
\hline \multirow{2}{*}{$\begin{array}{c}\text { Ordinal number } \\
\text { of trees }\end{array}$} & \multicolumn{5}{|c|}{ The intensity of the presence of fungi (\%) } \\
\hline & Alternaria & Penicillium & Trichothecium & Fusarium \\
\hline 2 & 2.7 & 9.9 & 3.5 & - \\
\hline 3 & - & 8.6 & 3.7 & - \\
\hline 5 & - & 7.4 & - & 1.5 \\
\hline 6 & 2.4 & - & - & - \\
\hline 7 & - & 6.8 & - & 0.7 \\
\hline 8 & 2.3 & 7.1 & 1.0 & 1.3 \\
\hline 9 & - & 6.5 & - & - \\
\hline 10 & 2.9 & 4.1 & - & - \\
\hline
\end{tabular}

\subsection{Entomological contamination of seeds}

Visible entomological damages on seeds were recorded in almost one-third of the harvested cones $(31.31 \%$, on the average), with even higher individual 
variability (in $0-80 \%$ of cones per tree) (Graph 2) than the phytopathological damages.

The presence of moth Dioryctria abietella (Denis \& Schiffermuller 1775), or Fir Coneworm, was determined in the tested material.

D. abietella of the order Lepidoptera, family Pyralidae, sub-family Phycitine, tribe Pictini (Karsholt et al. 2009). In the European fauna this family counts about one hundred species, whereas in our country approximately thirty have been recorded (Mihajlovic, 1978). This species belongs to the group of primary pests that feed on the cones and seeds of conifers. D. abietella is primarily the pest of the genus Picea but also frequent on species of the genus Pinus, Abies, Larix and Pseudotsuga.

D. abietella is among the 14 insect species that are the greatest pine pests, out of the total of 71 phytophagous species whose presence was found on species of the genus Pinus in Serbia (Mihajlovic, 2008).

This moth has a wingspan of $25-30 \mathrm{~mm}$. The front wings are ash-colored with white wavy cross black-lined stripes, while the back wings are whitish-grey. D. abietella does not express sexual dimorphism. This species of injurious moths has one generation per year. The moths swarm during the summer months of June and July. Females lay one or more eggs onto the cone base. Caterpillars are reddish-brown with a dark head and shield and dark stripes, up to $25 \mathrm{~mm}$ long. Upon hatching the caterpillars dig their way into cones, which is followed by abundant discharge of resin that may be connected to cobwebs and excrement (picture 1).

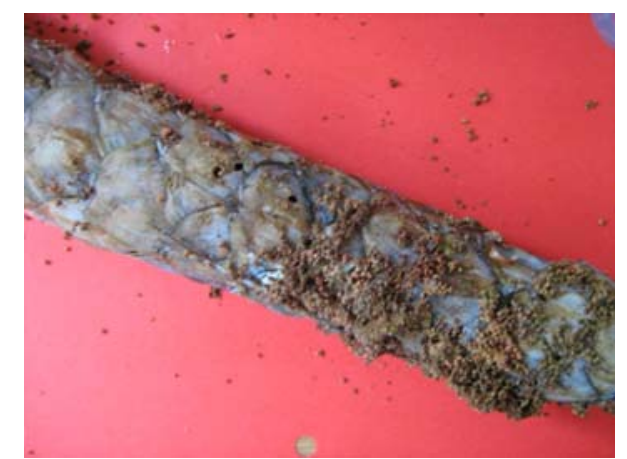

Picture 1. Dioryctria abietella-damaged cone of Pinus wallichiana (photo: K. Mladenović)

In certain years, in the absence of yield of a host plant, caterpillars may also develop in chermes galls and in newly grown increments. Due to its nutritive content, feeding on cones provides fir coneworm caterpillars the best conditions for development (Trudel et al, 1999). The cones get bitten into by one or more caterpillars. Caterpillars feed from the end of June until September on fertile scales and parts of seed. As a result of the damage, cones change their color to brown and remain on branches until autumn. In October caterpillars exit the cones by biting out round openings and move into the surface layer of the soil to spend the winter. In spring they undergo the pupae stadium. 


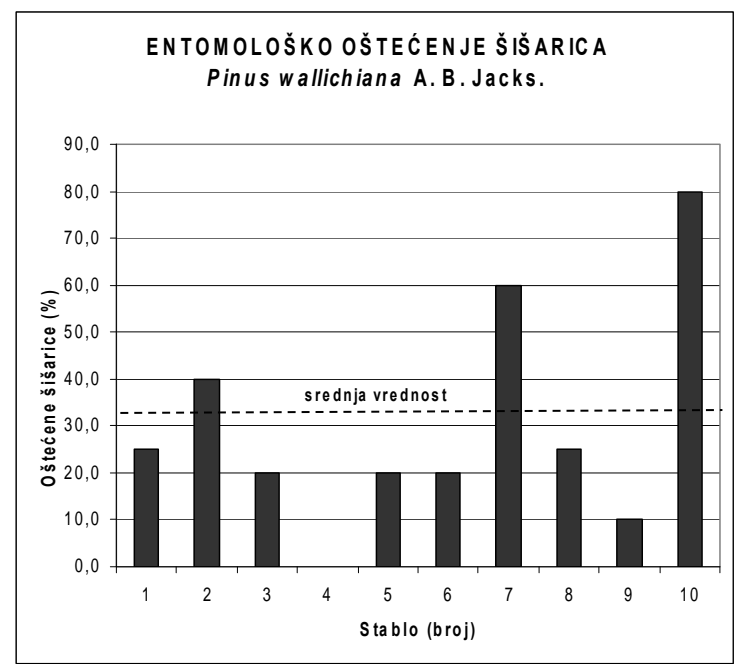

Graph. 2. Individual and average damages of cones by insects

\subsection{Seed Production}

A single cone contained between 14 and 142 seeds (on the average 78 seeds, Graph 3). The average number of seeds in cones of individual trees varied from 56 to 102 .

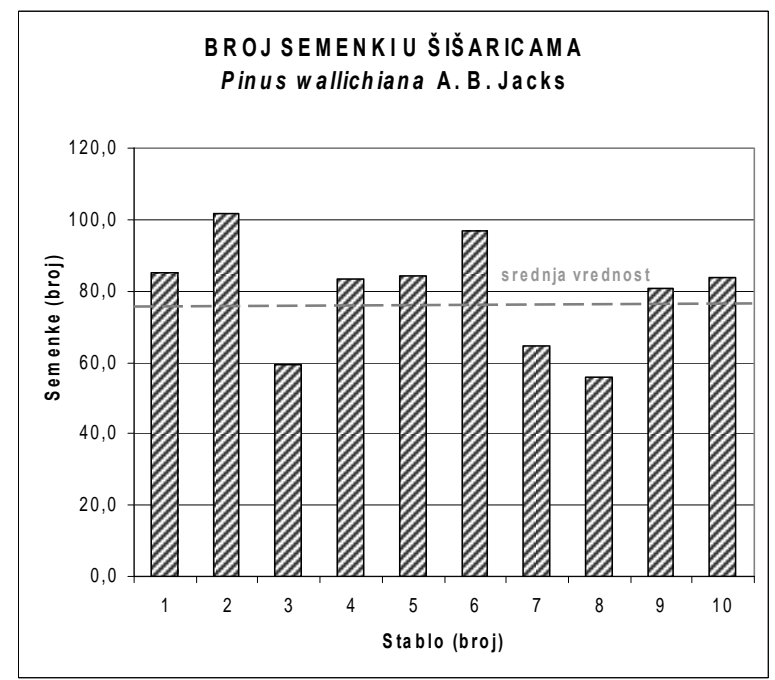

Graph. 3. Average production of seeds on individual and population levels

The comparison of results obtained from individual trees of the degree of damage (Graph 1, Graph 2) and seed production (Graph 3) was inconclusive and did not support the assumption of a significant link between phytopathological and entomological damages or their impact on seed production. 


\section{DISCUSSION}

The results obtained through testing the contamination of Himalayan pine seeds have confirmed a significant presence of phytopathological and entomological damages. However, only in a few cases may it be assumed (but not concluded) that such damages had a substantial impact on seed production. The reasons lie in the fact that the abundant flowering and seed production by forest trees are under strong genetic control and consequently subject to extreme individual variations (Anderson 1965; Ehrenberg 1963; Krstinić 1976; Milojević 1989; Nikolić et al, 2004). It has already been found that in mother trees, from which this forest culture was established, the number of seeds is in significant positive correlation with the cone length (Milojević, 1989). It is also known that the conifers have different individual responses to influences of the environment in the period of flowering and seeding (Lindgren et al, 1977). Climatic conditions in the period of seed development may also intensify the development of diseases and damage-causing insects. (Golubović Ćurguz et al, 2010).

The appearance and spreading of diseases on forest seeds and fruits depend primarily on external factors, place and manner of harvesting, the quality, way of processing, and finally methods and conditions of storing. Seeds get infected easily if the seed capsule is damaged. Fungi inhabit seeds and fruits in trees as well as later on, during the processing and storing phases. The results of laboratory analysis of the presence microflora on seeds have confirmed the presence of various parasitic fungi of genus Penicillium, which are often found on the surface of the seed and under certain conditions may penetrate not only cotyledons and endosperm of the seeds and cause a disease that spreads over to saplings and leads to damping-off. Seeds of conifers are particularly vulnerable, and the most dangerous fungi are those from the genus Fusarium. Similar results were obtained by Peno and Popović (1969) in their research on the presence of microflora in seeds of various types of pine and its impact on seed germination. The species they isolated most frequently were from genera Alternaria, Mucor, Rhizopus, Aspergillus, Penicillium, Trichotecium, Stemphylium, Paecilomyces, Thamnidium, Arthrobotrys and Fusarium. According to Timonin (1964), fungi from genera Alternaria, Aspergillus, Penicillium, Cladosporium, Cephalosporium, Chaetomium, Gliocladium, Aureobasidium and Trichoderma were isolated from seeds of various species. Based on the analysis of seed health condition, Lazarev et al (2003) determined that the fungi that predominate on the seeds harvested in registered seed facilities in Serbia are those from the genera Aspergillus and Penicillium.

According to Medngen et al (1996) and Vukojević i Duletić-Laušević (2004), pathogenic agents of disease of seeds and fruits may spread the infection through undamaged surfaces, through undamaged surfaces from the nearby affected seeds through other parts of the plants, or through injuries. Physiological injuries caused by the external factors may also create conditions for the development of pathogens.

In practice it is extremely difficult to prevent infections of seeds and fruits (cones) during their development on trees. Only in the phases of harvesting, processing and storing the seeds does it become possible to prevent the 
development and spreading of pathogenic fungi. Nonetheless, harvesting and sorting of cones from non-infected trees are considered to be the main measures of protection against agents of numerous diseases. In case of registered presence of diseases on cones and seeds, the recommended course of action is to separate and destroy the infected units, harvest the healthy ones, avoid mechanical damages during harvesting, transportation, sorting, cleaning and removal of moldy parts as centers of infection (Lazarev et al, 2003).

\section{CONCLUSIONS}

Measures of protection against agents of diseases in seeds include the following: keeping (storing) sufficient quantities of dried and healthy seeds in dry, well-aired premises at adequate air temperatures; removal of dirt and damaged seeds; storing of seeds in hermetically closed containers at the temperature of 0 to $5^{0} \mathrm{C}$; avoiding mechanical damages to seeds during harvesting and processing; frequent control of stored seeds, disinfection of seeds, tools, packaging, hermetical containers for keeping and storing of seeds.

In order to obtain healthy seeding material of high quality, seeds need to be disinfected prior to harvesting by applying preparations in dry or wet form. Over the last decade chemical and biological measures are being combined. The biological measures artificially introduce relevant antagonists that prevent the development of parasitic fungi into the soil (Ozbay and Newman, 2004).

D. abietella is an economically significant pest in cultures and stands of spruce, pine and fir. D. abietella is considered to be the most dangerous species for pine seed stands (Mihajlović, 2008). Cones attacked by this species have irregular development. Mechanical damages to seeds occur due to moths feeding on the cones. Caterpillar bites cause abundant discharge of resin, and as a consequence the cones under attack do not open. In certain years this pest develops massively. $D$. abietella causes major damage while drilling its way into sprouts, which results in irregular growth of the attacked tree.

Pest control can be done mechanically, before the attacked cones fall off or immediately thereafter, but still before the caterpillars going into the soil for the winter exit the cones. Chemical treatments may be administered during the flight of imago, in June and July.

\section{REFERENCES}

Anderson, E. (1965): Cone and seed studies in Norway spruce (Picea abies (L.) Karst.). Studia Forestalia Suecica, 23: 8-46.

Bunuševac, T. (1959): Uslovi sredine zone A Novog Beograda. Direkcija za izgradnju Novog Beograda, Beograd, pp. 5-48.

Carmichael, J. W., Kendrick W. B., Conners, I.L., Sigler L. (1980): Genera of Hyphomycetes. The University of Alberta Press. Edmonton.

Dennis R.V.G. (1978): British Ascomycetes. J. Cramer, Vaduz, p.585. 
Dražić, D. (1997): Proučavanje stanja i funkcionalnosti rekultivisanih odlagališta pošumljavanjem na području Kolubarskog basena u cilju kvalitetnije životne sredine i njenog korišćenja za rekreaciju. Doktorska disertacija, Šumarski fakultet, Beograd, pp. 157158.

Ehrenberg, C. E. (1963): Genetic variation in progeny tests of Scots pine (P. sylvestris L.). Studia Forestalia Suecica, 10: 5-20.

Golubović-Ćurguz, V., Nikolić, B. (1999): Ispitivanje fitopatološke zaraženosti semena Pinus wallichiana A. B. Jacks. i njenog uticaja na klijavost. Šumarstvo, 1-2: 79- 84.

Golubović Ćurguz, V., Tabaković-Tošić, M., Rajković, S. (2010) : Climate change effects on pathogens and harmful insects, International Scientific Conference: Forest ecosystems and climate changes, 9-10 ${ }^{\text {th }}$ march 2010, Belgrade, Plenary lectures, pp.179-188 .

Karsholt, Dr Ole \& van Nieukerken, Dr Erik J._(2009) Fauna Europaea: Insecta, Lepidoptera. Fauna Europ. version 2.1,http://www.faunaeur.org

Krstinić, A. (1976): Varijabilnost bujnosti rasta i pravnosti debla hibrida bjele vrbe (Salix alba L.) i krhke vrbe (Salix fragilis L.). Doktorska disertacija, Univerzitet Zagreb, pp. 103245.

Lazarev, V., Golubović-Ćurguz, V., Marković M. (2003): Forest seed diseases and protection measures. Sbornik naučni dokladi. Procedings of Scientific Paper, Sofija.

Vol. II :205-211.

Lindgren, K., Ekberg, I., Eriksson, G. (1977): External factors influencing female

flowering in Picea abies (L.) Karst. Studia Forestalia Suecica, 142: 5-52.

Mihajlović, Lj. (2008): Najvažnije štetne vrste insekata bora, smrče i jele u Srbiji. Šmarstvo, vol. 60, br. 3, str. 65-81.Beograd

Mihajlović, Lj. (2008): Šumarska entomologija, Univrzitet u Beogradu, Čumarski fakultet

Mihajlović, Lj. (1978): Prvi prilog poznavanju superfamilije Pyraloidea SR Srbije. SANU, Odeljenje prirodno matematičkih nauka: Zbornik radova o entomofauni SR Srbije, knj II: 177-201. Beograd

Milojević, B. (1989): Varijabilnost, adaptivnost i mogućnosti selekcije himalajskog bora (Pinus wallichiana A. B. Jacks.). Magistarski rad, Šumarski fakultet, Beograd, 225 p.

Milojević-Nikolić, B. (1991): Prilog introdukciji himalajskog bora (Pinus wallichiana A. B. Jacks.). Simpozijum "Nedeljko Košanin i botaničke nauke" (10-13. oktobar 1990), Ivanjica, pp. 279-282.

Milojević-Nikolić, B. (1992): Rezultati dvogodišnje analize cvetanja i uroda stabala himalajskog bora (Pinus wallichiana A. B. Jacks. ) u uslovima Beograda i okoline. Glasnik Šumarskog fakulteta, 74 (II): 519-526.

Mendgen, K., Hahn, M., Deising, H. (1996): Morphogenesis and mechanizms of penet ration by Plant pathogenic fungi. Annu. Rev. Phytopatol. 34: 367-386.

Nikolić, B. (1996): Varijabilnost važnijih svojstava polena himalajskog bora - populacija Novi Beograd. Zbornik Instituta za šumarstvo, 40-41: 27 -33.

Nikolić, B. (1997): Evaluation of The Genetic Potential of Himalayan Pine (Pinus wallichiana A. B. Jacks.) For Breeding Purposes. " 3 rd International Conference on the 
Development of Forestry and Wood Science Technology - ICFWST Belgrade - Goč“ (29. IX -3. X 1997, '97), Proceedings, Vol. II, pp. 59-63.

Nikolić, B., Marković, D., Grbović, B. (1998): Development of Pinus wallichiana A. B. Jacks., Culture Established in The Process of Recultivation of Opencast Lignite Mine Waste Dumps. "70-th Anniversary of the Forest Research Institute" (6 -7. October 1998), Sofia, Bulgarian Academy of Sciences, Forest Research Institute, Scientific Papers, Vol. II: $122-127$.

Nikolić, B., Batos, B., Dražić, D. (2004): Rast i cvetanje kao parametri razvoja mlade kulture Pinus wallichiana A. B. Jacks. osnovane u procesu rekultivacije deposola. Treća medjunarodna konferencija o upravljanju zaštitom okoline "Energetska efikasnost u energetici (ELECTRA III) “, Herceg Novi, (7-11.juni 2004), Zbornik radova, pp. 468-470.

Ozbay, N., Newman, S.E. (2004): Biological Control with Trichoderma spp. With Emphasis on T. harzianum. Pakistan Journal of Biological Sciences, 7 (4) : 478-484.

Peno, M., Popović,J. (1969): Gljivična mikroflora semena Pinus nigra Arn. i Pinus silvestris L. i njen uticaj na klijanje semena. Zbornik radova Instituta za šumarstvo, Tom IX, str, 101116.

Sutton, B.C. (1980): The Coleomycetes. Fungi Imperfecti with Pycnidia Acervuli and Stromata. CAB- Commonwealth Mycological Institute, Kew, Surrey, England p. 696

Timonin, M.I. (1964): Interaction of seed-coat microflora and soil microorganisms and its effects on pre-and post-emergence of some conifer seedlings. Can. J. Microbiol.10: 17-22.

Trudel, R., Bauce, E., Guertin, C., Cabana, J.(1999): Performance of the fir coneworm Dioryctria abietivorella as affected by host cpecies and presence or absence of seed cones. Agricultural and Forest Entomology 1, 189-194

Vajda, Z. (1974): Nauka o zaštiti šuma. Školska knjiga-Zagreb. str. 264-265

Vidaković, M. (1982): Četinjače. Morfologija i varijabilnost. JAZU I Sveučilišna naklada Liber, Zagreb, 428 p.

Vukojević, J., Duletić-Laušević,S. (2004): Patogene gljive povrća i voća u Srbiji. NNK Internacional, Beograd

Živojinović, S. (1968): Šumarska entomologija. Naučna knjiga. Beograd

\title{
DISEASES AND INJURIES OF HIMALAYAN PINE SEED FROM CULTURE GROWN ON DEPOSOL
}

\author{
Vesna GOLUBOVIĆ ĆURGUZ, Katarina MLADENOVIĆ, \\ Biljana NIKOLIĆ, Snežana RAJKOVIĆ
}

\section{Summary}

From young forest culture of Pinus wallichiana, which was established on loamy deposol, about one hundred of nearly ripe cones were harvested. Opening of cone scales and dropping of seed grains in laboratory conditions were induced. Damages caused by the presence of fungi organisms in $18.28 \%$ of cones (in average) were recorded, with expressed individual variability $(0-50 \%)$. The most often present were fungi prom genus Penicillium $(50.4 \%)$, Alternaria and Trichothecium, while the rarest ones originated from genus Fusarium (3.5\%). 
On the cone entomological damage caused by feeding moth Dioryctria abietella are determined which belongs to the most important pine pests of 71 phytophagous species whose presence is found in species on genus Pinus, for the area of Serbia. Changes caused by this species of moth were recorded in almost every third cones $(31.31 \%)$ were recorded, with much more expressed variability between genotypes (0-80\%).

Although phytopathological and entomological damages on the cones of Himalayan pine were significant, the degree to which they affected the seed production cannot be determined with certainty, because the abundance of flowering and seed bearing in forest trees are under strong genetic control.

In practice it is very difficult to prevent infection of seeds and fruits (cones) as well as the attacks of insects during their development on the trees. Collecting cones with non-infected trees and their selection, as well as the destruction of the infected ones are the main protective measures in the seed processing. Measures to protect seeds from diseases include several measures: keeping of seeds (and cones) dry and healthy, ventilation of rooms specified for keeping cones and seeds and avoiding mechanical damages of cones and seeds during their collection and processing. In order to obtain better quality and healthier plant material it is necessary to disinfect seeds before planting by applying chemical or biological products.

D. abietella can be controlled by mechanical and chemical means. For mechanical control attacked cones must be collected from trees or the land immediately after the decline and before larva leave the track. Gathered cones must be cremated. Chemical treatment must be made by contact insecticides during the flight of imago, in June and July.

\title{
BOLESTI I OŠTEĆENJA SEMENA U KULTURI HIMALAJSKOG BORA GAJENOG NA DEPOSOLU
}

\author{
Vesna GOLUBOVIĆ ĆURGUZ, Katarina MLADENOVIĆ, \\ Biljana NIKOLIĆ, Snežana RAJKOVIĆ
}

\section{Rezime}

Iz mlade šumske kulture Pinus wallichiana osnovane na ilovastom deposolu, sakupljeno je oko 100 poluzrelih šišarica. U laboratorijskim uslovima indukovano je otvaranje njihovih plodnih ljuspi i ispadanje semena. Oštećenja semena usled prisustva gljivičnih organizama evidentirana su kod 18.28\% šišarica (u proseku), sa jako izraženom individualnom varijabilnošću (0-50\%). Na semenu sa analiziranih stabala konstatovane su gljive iz sledećih rodova Alternaria, Fusarium, Penicillium, Trichothecium. Najčešće su konstatovane vrste gljiva iz roda Penicillium (na 50.4\% analiziranog semena), a najmanje su bile prisutne gljive iz roda Fusarium (3.5\% analiziranog semena).

$\mathrm{Na}$ šišaricama su utvrđena entomološka oštećenja izazvana ishranom leptira plamenca Dioryctria abietella koji pripada grupi najznačajnijih štetočina bora od ukupno 71 fitofagne vrste čije je prisustvo utvrđeno na vrstama roda Pinus kod nas. Promene koje izaziva ova vrsta leptira evidentirana su kod gotovo svake treće šišarice $(31.31 \%)$ sa još jače izraženom varijabilnošću između genotipova $(0-80 \%)$.

Mada su fitopatološka i entomološka oštećenja na semenu himalajskog bora značajna, ne može se sa sigurnošću utvrditi u kom su stepenu uticala na produkciju semena, jer su obilnost cvetanja i radjanja semena kod šumskog drveća pod jakom genetskom kontrolom.

U praksi je vrlo teško sprečiti infekcije semena i plodova (šišarki) kao i napade insekata za vreme njihovog razvoja na drveću. Sakupljanje šišarki sa nezaraženih stabala i njihovo prebiranje, kao i uništavanje zaraženih u postupku dorade su glavne zaštitne mere. 
Mere zaštite od uzročnika bolesti semena obuhvataju više mera: čuvanje dovoljno prosušenog i zdravog semena (šišarki) u suvim, ventilisanim prostorijama, izbegavanje mehaničkog oštećivanja semena pri sakupljanju i doradi.

Da bi se dobio što kvalitetniji i zdraviji sadni materijal potrebno je uraditi dezinfekciju semena pre setve primenom hemijskih (odabir preparata za zaštitu vrši se u skladu sa postojećom nacionalnom zakonskom regulativom) ili bioloških preparata .

Suzbijanje $D$. abietella se vrši mehanički i hemijski. Za mehaničko suzbijanje potrebno je napadnute šišarke, koje su promenile boju, sakupiti sa stabla ili ili zemljišta neposredno po opadanju a pre no što ih gusenice napuste. Sakupljenje šišarke spaliti.. Hemijsko tretiranje izvršiti kontaktnim insekticidima tokom leta imaga, u junu i julu. 